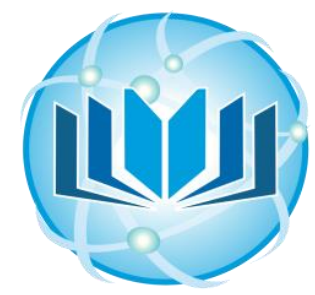

\title{
Dentin Disinfection Efficacy Using Four Different Irrigation Protocols
}

\section{David Jaramillo ${ }^{1}$, Jose L Ibarrola ${ }^{2}$, Ana Arias ${ }^{3}$, Phillipe Sleiman ${ }^{4,5}$, Ali Naji ${ }^{6}$} and David E Jaramillo ${ }^{6^{*}}$

\section{Affiliation}

${ }^{1}$ Midwestern University, Glendale, Arizona

${ }^{2}$ Creighton University, School of Dentistry, Omaha, USA

${ }^{3}$ Department of Conservative Dentistry, Complutense University of Madrid, Spain

${ }^{4}$ University of North Carolina, North Carolina, USA

${ }^{5}$ Lebanese University, Beirut, Lebanon

${ }^{6}$ University of Texas, Health Science Center, Houston TX, USA

*Corresponding author: David E Jaramillo, University of Texas, Health Science Center, 7500 Cambridge St, Houston TX, USA 77054, E-mail: David.E.Jaramillo@uth.tmc.edu

Citation: Jaramillo D, Ibarrola JL, Arias A, Sleiman P, Naji A, et al. Dentin disinfection efficacy using four different irrigation protocols (2021) Dental Res Manag 5: 33-37.

Received: Aug 30, 2021

Accepted: Oct 08, 2021

Published: Oct 15, 2021

Copyright: @ 2021 Jaramillo D, et al., This is an open-access article distributed under the terms of the Creative Commons Attribution License,

which permits unrestricted use, distribution, and reproduction in any medium, provided the original author and source are credited.

\begin{abstract}
Objective: The objective of this study was to observe the effect that 3\% Sodium Hypochlorite and 17\% Ethylenediamine Tetraacetic Acid (EDTA) with water in between, used sequentially and individually had in the disinfection of dentin blocks that were contaminated with Enterococcus faecalis.

Materials and Methods: Thirty apical and coronal dentin block samples were divided into five groups $(\mathrm{n}=5)$ : All samples were inoculated with Enterococcus faecalis Group 1: Samples were submerged in 3\% $\mathrm{NaOCl}$ then in 17\% EDTA. Group 2: Samples were submerged first in 17\% EDTA and then in 3\% NaOCl. Group 3: Samples were immersed in 3\% $\mathrm{NaOCl}$ only. Group 4: Samples were submerged in $17 \%$ EDTA only. Group 5 (positive control group): Samples were only submerged in distilled water. All samples were submerged in distilled water after each irrigation cycle. The irrigation protocol was repeated in all groups until all dentin samples were exposed to $24 \mathrm{ml}$ of the irrigating solutions. CFU units were counted and classified in an ordinal scale and compared with the linear-by-linear association test.

Results: A significant linear trend in the reduction of $\mathrm{CFU}$ was observed when $\mathrm{NaOCl}$ and EDTA were combined (independently of the sequence used) when compared to groups 3 and 4 where the irrigants were used individually both in coronal ( $\mathrm{p}=9.45 \mathrm{x} 10-21)$, and apical slices $\left(\mathrm{p}=2.33 \times 10^{-20}\right) . \mathrm{NaOCl}$ was significantly more effective than EDTA in both coronal and apical slices $(\mathrm{p} \geq 0.000001)$ when used alone.

Conclusion: $3 \%$ Sodium Hypochlorite was more effective than 17\% EDTA. However, alternating 3\% NaOCl with $17 \%$ EDTA resulted in better dentinal disinfection.

Clinical Relevance: Establishing an irrigation protocol that is effective in eradicating bacteria entrenched in dentinal tubules can lead to a more successful outcome in endodontically treated teeth.

Keywords: Endodontics, Root canal irrigation, $\mathrm{NaOCl}$, EDTA

Abbreviations: EDTA-Ethylenediamine Tetraacetic Acid, NaOCl-Sodium Hypochlorite, CFU-Colony Forming Unit
\end{abstract}

\section{Introduction}

The relationship between pulpal and periradicular pathology and microorganisms has been well established [1-2]. Endodontic therapy aims to at reduce as much as possible the bacterial load of contaminated root canal systems. Numerous techniques and antimicrobial agents have been suggested and utilized to achieve this goal [3]. Sodium Hypochlorite $(\mathrm{NaOCl})$ as a sole irrigation agent at first or in combination with other solutions has been the most widely utilized irrigant in root canal therapy. Factors such as concentration of the solution, time of contact with microorganisms, and irrigation volume are important factors in the effectiveness of irrigating solutions. $\mathrm{NaOCl}$ is used in concentrations ranging from $0.5 \%$ to $6 \%$. $\mathrm{NaOCl}$ is a potent antimicrobial agent and has the capacity to dissolve and digest pulpal tissue remnants [4].
Enterococcus faecalis is a facultative anaerobic gram-positive coccus that is resistant to intracanal medications and able to invade dentinal tubules [5]. Vieira et al [6] described dentinal tubule infection as a cause of endodontic treatment failure. Gomes et al. [7] tested the effect of various concentrations of $\mathrm{NaOCl}$ in vitro on Enterococcus faecalis and found it to be efficient in killing the bacteria in less than 30 seconds while using a $5.25 \% \mathrm{NaOCl}$ solution, conversely when using a $0.5 \%$ solution of $\mathrm{NaOCl}$ it took 30 minutes to eliminate $E$. faecalis colonies. To achieve their maximum antimicrobial efficacy irrigation solutions must come in direct contact with microorganisms, dentin debris can impede $\mathrm{NaOCl}$ from direct contact with bacteria thus reducing its efficacy [8]. Root canal anatomy can present an

Citation: Jaramillo D, Ibarrola JL, Arias A, Sleiman P, Naji A, et al. Dentin disinfection efficacy using four different irrigation protocols (2021) Dental Res Manag 5: 33-37. 
obstacle in preventing thorough chemo-mechanical preparation of the root canal space [9]. Furthermore, bacteria can become imbedded deep inside dentinal tubules where they cannot be reached by the antibacterial solutions [10-11]. Cleaning and shaping procedures have been shown to heighten this problem by producing debris deposits that contribute to the formation of smear layer [12]. In addition, dentin itself can have a neutralizing effect on root canal medicaments. Haapasalo et al [13] showed that the presence of dentin delayed the effectiveness of $1 \% \mathrm{NaOCl}$ in eliminating E. faecalis. Also, it has been shown that $\mathrm{NaOCl}$ alone is unable to remove the smear layer [14].

At the same time, the use of intracanal chelator solutions such as EDTA have been shown to be effective in the removal of the inorganic portion of the smear layer thus making the dentinal tubules more accessible to irrigation solutions and improving the bacterial effectiveness of disinfecting solutions in deeper layers of dentin $[10,15]$. EDTA and $\mathrm{NaOCl}$ have been shown to be more effective in disinfecting and cleaning dentinal tubules when used sequentially than when used as independent agents. Wang et al [16] demonstrated that alternating the use of $\mathrm{NaOCl}$ and EDTA with water in between is more efficient in keeping dentinal tubules open during cleaning and shaping procedures that when using $\mathrm{NaOCl}$ or EDTA alone. While EDTA does not possess significant antimicrobial properties, it can enhance the effectiveness of other antimicrobial agents by allowing their dissemination into otherwise inaccessible dentinal tubules that can potentially harbor microorganisms [17].

The aim of this study was to analyze the effect of different irrigation protocols that included 3\% Sodium Hypochlorite and 17\% EDTA, used both sequentially and individually, in the disinfection of dentin blocks contaminated with $E$. faecalis. It is also of interest to see if increasing the volume and contact time with these irrigants would influence dentin disinfection.

\section{Materials and Methods}

\section{Sample collection and sample preparation}

Thirty dentinal block slices each measuring $3 \mathrm{~mm} \times 5 \mathrm{~mm}$ were obtained from teeth (maxillary 1 rooted premolars) collected from the Oral and Maxillofacial Surgery and Periodontics departments at the University of Texas Health Science Center at Houston, Texas. Dentin sample sections measuring $3 \times 5 \mathrm{~mm}$ were obtained with an Isomet 1000 precision saw (Buehler, Lake Bluff, IL). After the sectioning procedure was completed each dentin sample was submerged in a micro-test tube containing 17\% EDTA to remove any residual smear layer that might have been produced during sectioning. All samples were autoclaved at a temperature of $121^{\circ} \mathrm{C}$ at 20 PSI for 20 minutes. The specimens were then placed in 250-ml Erlenmeyer flasks (Nova Tech International, Kingwood, TX) filled with Brain Heart Infusion (BHI) media and inoculated with E. faecalis, to an optical density of 1 (=20 million bacterial units). The flasks were placed in an incubator (Shel Lab, Vernon Hills, IL) for a period of three weeks at $37^{\circ} \mathrm{C}$. Apical and coronal samples were obtained from the contaminated dentin blocks and designated and $\mathrm{b}$ respectively.

\section{Experimental groups and controls}

Depending on the irrigation protocol used, the samples were randomly divided into four experimental groups and one positive control group (Table 1) as follow:

Group 1: 3\% sodium hypochlorite was used followed with immersion in distilled water, then submerged in $17 \%$ EDTA and immersed in distilled water. The process was repeated until exposure to the irrigants reached $24 \mathrm{ml}$.

Group 2: 17\% EDTA was used followed with immersion in distilled water, then submerged in 3\% sodium hypochlorite and immersed in distilled water. The process was repeated until exposure to the irrigants reached $24 \mathrm{ml}$.
Group 3: Only 3\% sodium hypochlorite was used in this group with intermittent exposure to distilled water. The process was repeated until exposure to the irrigants reached $24 \mathrm{ml}$.

Group 4: Only 17\% EDTA was used in this group with alternating exposure to distilled water. The process was repeated until exposure to the irrigants reached $24 \mathrm{ml}$.

Group 5 (positive control group): Only distilled water was used in this group and was designated as the positive control group (Figure 1 to Figure 5).

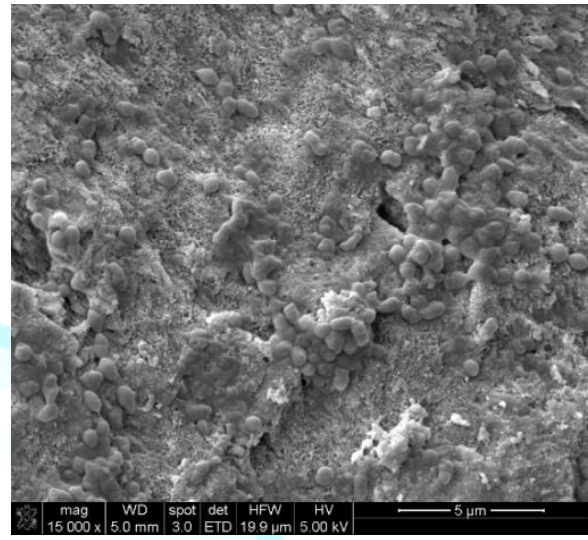

Figure 1: Positive Control. SEM images demonstrated cells growth on top of dentin blocks.

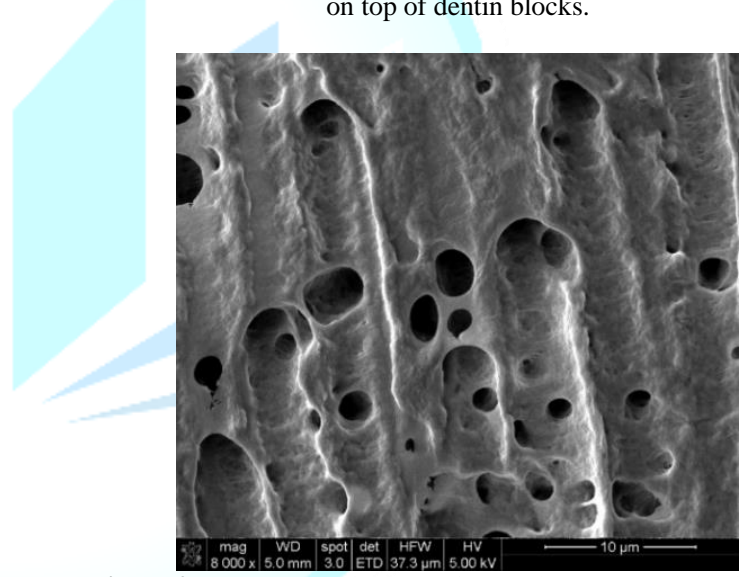

Figure 2: Groups 1 and 2. SEM image demonstrated dentin block condition after treatment. Both groups showed similar removal of debris and cells characteristics.

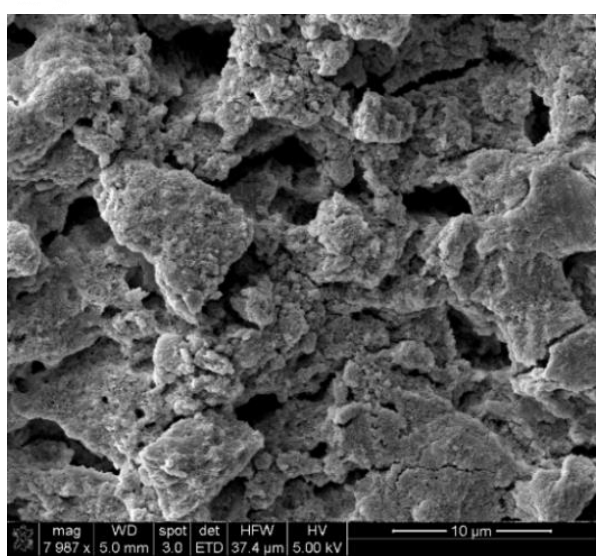

Figure 3: $\mathrm{NaOCl}$ group. $\mathrm{NaOCl}$ showed no evidence of debris removal from dentin blocks surface. 


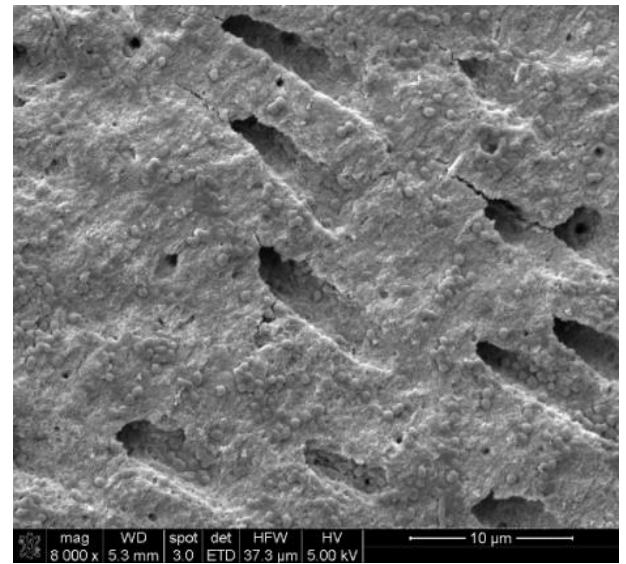

Figure 4: EDTA group. EDTA show some disruption of inorganic debris attached to dentin blocks.

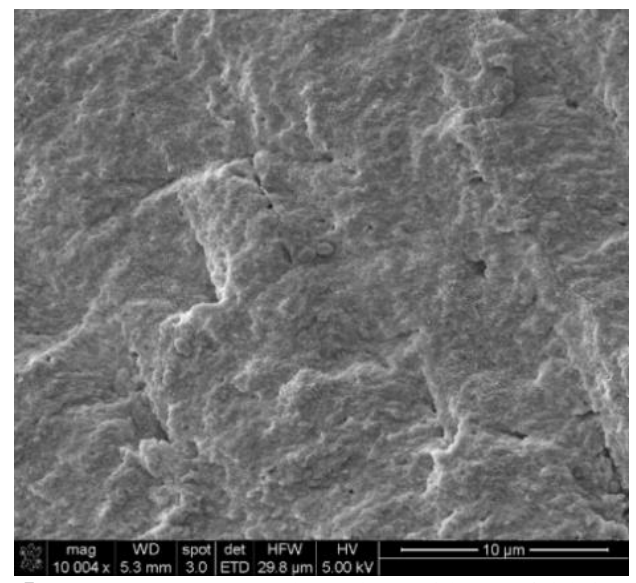

Figure 5: Water group. Water showed no evidence of debris removal from dentin blocks surface.

\begin{tabular}{|c|c|c|c|c|c|c|c|c|c|c|c|c|}
\hline Group 1 & $\begin{array}{c}\mathrm{NaOCl} \\
3 \mathrm{ml}\end{array}$ & $\begin{array}{c}\text { Water } \\
1 \mathrm{ml}\end{array}$ & $\begin{array}{c}\text { EDTA } \\
3 \mathrm{ml}\end{array}$ & $\begin{array}{c}\text { Water } \\
1 \mathrm{ml}\end{array}$ & $\begin{array}{c}\mathrm{NaOCl} \\
3 \mathrm{ml}\end{array}$ & $\begin{array}{c}\text { Water } \\
1 \mathrm{ml}\end{array}$ & $\begin{array}{c}\text { EDTA } \\
3 \mathrm{ml}\end{array}$ & $\begin{array}{c}\text { Water } \\
1 \mathrm{ml}\end{array}$ & $\begin{array}{c}\mathrm{NaOCl} \\
3 \mathrm{ml}\end{array}$ & $\begin{array}{c}\text { Water } \\
1 \mathrm{ml}\end{array}$ & $\begin{array}{c}\text { EDTA } \\
3 \mathrm{ml}\end{array}$ & $\begin{array}{c}\text { Water } \\
1 \mathrm{ml}\end{array}$ \\
\hline Group 2 & $\begin{array}{c}\text { EDTA } \\
3 \mathrm{ml}\end{array}$ & $\begin{array}{c}\text { Water } \\
1 \mathrm{ml}\end{array}$ & $\begin{array}{c}\mathrm{NaOCl} \\
3 \mathrm{ml}\end{array}$ & $\begin{array}{c}\text { Water } \\
1 \mathrm{ml}\end{array}$ & $\begin{array}{c}\text { EDTA } \\
3 \mathrm{ml}\end{array}$ & $\begin{array}{c}\text { Water } \\
1 \mathrm{ml}\end{array}$ & $\begin{array}{c}\mathrm{NaOCl} \\
3 \mathrm{ml}\end{array}$ & $\begin{array}{c}\text { Water } \\
1 \mathrm{ml}\end{array}$ & $\begin{array}{c}\text { EDTA } \\
3 \mathrm{ml}\end{array}$ & $\begin{array}{c}\text { Water } \\
1 \mathrm{ml}\end{array}$ & $\begin{array}{c}\mathrm{NaOCI} \\
3 \mathrm{ml}\end{array}$ & $\begin{array}{c}\text { Water } \\
1 \mathrm{ml}\end{array}$ \\
\hline Group 3 & $\begin{array}{c}\mathrm{NaOCl} \\
3 \mathrm{ml}\end{array}$ & $\begin{array}{c}\text { Water } \\
1 \mathrm{ml} \\
\end{array}$ & $\begin{array}{c}\mathrm{NaOCl} \\
3 \mathrm{ml} \\
\end{array}$ & $\begin{array}{c}\text { Water } \\
1 \mathrm{ml}\end{array}$ & $\begin{array}{c}\mathrm{NaOC} 1 \\
3 \mathrm{ml} \\
\end{array}$ & $\begin{array}{c}\text { Water } \\
1 \mathrm{ml}\end{array}$ & $\begin{array}{c}\mathrm{NaOC} 1 \\
3 \mathrm{ml}\end{array}$ & $\begin{array}{c}\text { Water } \\
1 \mathrm{ml}\end{array}$ & $\begin{array}{c}\mathrm{NaOCI} \\
3 \mathrm{ml}\end{array}$ & $\begin{array}{c}\text { Water } \\
1 \mathrm{ml}\end{array}$ & $\begin{array}{c}\mathrm{NaOCI} \\
3 \mathrm{ml}\end{array}$ & $\begin{array}{c}\text { Water } \\
1 \mathrm{ml} \\
\end{array}$ \\
\hline Group 4 & $\begin{array}{c}\text { EDTA } \\
3 \mathrm{ml}\end{array}$ & $\begin{array}{c}\text { Water } \\
1 \mathrm{ml}\end{array}$ & $\begin{array}{c}\text { EDTA } \\
3 \mathrm{ml}\end{array}$ & $\begin{array}{c}\text { Water } \\
1 \mathrm{ml}\end{array}$ & $\begin{array}{c}\text { EDTA } \\
3 \mathrm{ml}\end{array}$ & $\begin{array}{c}\text { Water } \\
1 \mathrm{ml}\end{array}$ & $\begin{array}{c}\text { EDTA } \\
3 \mathrm{ml}\end{array}$ & $\begin{array}{c}\text { Water } \\
1 \mathrm{ml}\end{array}$ & $\begin{array}{c}\text { EDTA } \\
3 \mathrm{ml}\end{array}$ & $\begin{array}{c}\text { Water } \\
1 \mathrm{ml}\end{array}$ & $\begin{array}{c}\text { EDTA } \\
3 \mathrm{ml}\end{array}$ & $\begin{array}{c}\text { Water } \\
1 \mathrm{ml}\end{array}$ \\
\hline Group 5 & $\begin{array}{c}\text { Water } \\
2 \mathrm{ml}\end{array}$ & $\begin{array}{c}\text { Water } \\
2 \mathrm{ml}\end{array}$ & $\begin{array}{l}\text { Water } \\
2 \mathrm{ml}\end{array}$ & $\begin{array}{c}\text { Water } \\
2 \mathrm{ml}\end{array}$ & $\begin{array}{c}\text { Water } \\
2 \mathrm{ml}\end{array}$ & $\begin{array}{c}\text { Water } \\
2 \mathrm{ml}\end{array}$ & $\begin{array}{c}\text { Water } \\
2 \mathrm{ml}\end{array}$ & $\begin{array}{c}\text { Water } \\
2 \mathrm{ml}\end{array}$ & $\begin{array}{c}\text { Water } \\
2 \mathrm{ml}\end{array}$ & $\begin{array}{l}\text { Water } \\
2 \mathrm{ml}\end{array}$ & $\begin{array}{c}\text { Water } \\
2 \mathrm{ml}\end{array}$ & $\begin{array}{c}\text { Water } \\
2 \mathrm{ml}\end{array}$ \\
\hline
\end{tabular}

Table 1: Irrigation sequence per group.

Dentin block samples in the experimental groups were individually immersed in $2 \mathrm{ml}$ Eppendorf tubes (Eppendorf North America, Hauppauge NY) that contained $1 \mathrm{ml}$ of the irrigation solution. The irrigant was replenished every 20 seconds with $1 \mathrm{ml}$ of fresh solution until the dentin block samples were exposed to $3 \mathrm{ml}$ of the solution in one minute. The dentin blocks were then submerged in $1 \mathrm{ml}$ of distilled water for one minute. Samples were then immersed in $1 \mathrm{ml}$ of the next designated irrigating solution and after 20 seconds the irrigant was replenished with fresh solution until dentin exposure to the irrigant reached $3 \mathrm{ml}$ in one minute. The samples were then immersed in $1 \mathrm{ml}$ of distilled water for one minute.

This sequence was repeated until all experimental samples were exposed to the irrigating solutions for a total of $24 \mathrm{ml}$. One group was designated the positive control group and was exposed to $2 \mathrm{ml}$ of distilled water which was replenished every minute until the samples were exposed to $24 \mathrm{ml}$ of water. After each exposure the samples that were immersed in $\mathrm{NaOCl}$ were submerged for five minutes in a $5 \%$ sodium thiosulfate solution to inactivate any $\mathrm{NaOCl}$ residues. At the end of the irrigation cycles all dentin block samples were individually placed in Eppendorf tubes filled with Phosphate Buffered Solution (PBS) and agitated with a Vortex Genie 2 mixer. $30 \mu 1$ of the suspension was collected from each tube and seeded in BHI agar plates. All samples were incubated for 24 hours and CFU were counted using Dahlen et al. [18] methodology. Data was classified as follow: 1=1-10 CFU; 2=11-100 CFU; 3=101-1000 CFU; 4=100110000 CFU; $5=+10000 \mathrm{CFU}$ (Table 2).

\begin{tabular}{|c|c|}
\hline Score & CFU \\
\hline 1 & $1-10$ \\
\hline 2 & $11-100$ \\
\hline 3 & $101-1000$ \\
\hline 4 & $1000-10000$ \\
\hline 5 & $>10001$ \\
\hline
\end{tabular}

Table 2: CFU scoring.

\section{Statistical Analysis}

The ordinal (linear) chi-square test, also known as the linear-by-linear association test, was used to compare the effectiveness of the different irrigation protocols and assess any difference in the trend to reduce CFU among groups both for coronal and apical slices.

\section{Results}

CFU for all samples in the positive control group was higher than 100000. Results for each irrigation regimen for both coronal and apical tooth slices are shown in Table 2. No significant differences were detected between groups 1 and 2 for apical $(\mathrm{p}=1)$ or coronal slices $(p=0.74)$. However, a significant linear trend in the reduction of $\mathrm{CFU}$ was observed in those groups where $\mathrm{NaOCl}$ and EDTA were combined (independently of the sequence used) when compared to groups 3 and 4 where the irrigants were used individually both coronal $\left(\mathrm{p}=9.45 \times 10^{-21}\right)$, and apical slices $\left(\mathrm{p}=2.33 \times 10^{-20}\right)$. At the same time, $\mathrm{NaOCl}$ as only irrigant was significantly more effective than EDTA in both coronal and apical slices $(\mathrm{p} \geq 0.000001)$.

\section{Discussion}

This in vitro study was designed to assess the effectiveness of different irrigation protocols on dentin block slices contaminated with E. faecalis. A key element on successful endodontic outcomes is the eradication of microbes from the root canal system. This goal is accomplished by mechanical instrumentation in conjunction with copious irrigation of the root canal. However, bacteria can remain in inaccessible parts of the canal where mechanical instruments and irrigation solutions cannot reach [19]. Once pulpal necrosis occurs infected dentinal tubules can become an important reservoir from which canal reinfection can occur [20]. Furthermore, Veira et al [6] published a case report of a long- term treatment failure that was attributed to dentinal tubule infection. It has been proposed that bacteria can penetrate deep into dentinal tubules, making it difficult 
for irrigating solutions and medicaments to penetrate and eliminate bacteria from contaminated dentin [21].

Sedgley [22] observed that E. faecalis could remain viable ex vivo after treatment and provide a long term-nidus that can induce subsequent endodontic disease. Therefore, it is important to disinfect not only the root canal space but also the surrounding dentin as well. Different irrigation solutions have been used with reports of varying degrees of success [23]. Factors that affect the effectiveness of these irrigating solutions are the concentration of the irrigation solution; volume utilized, delivery method utilized, and contact time of the irrigation solution with the affected area [3]

This study compared the effectiveness of irrigation solutions used as single irrigants and contrasted them to the same irrigation solutions used in combination. The order in which the irrigation solutions were utilized was exchanged to see if a certain irrigation protocol was more effective in eliminating bacteria from dentinal tubules. Distilled water was used as an intermediate irrigant to reduce the interaction between the different irrigating solutions which could potentially reduce the irrigant effectiveness or result in the production of undesirable byproducts [24]. Wang et al. [16] showed that alternating the use of $\mathrm{NaOCl}$ and EDTA with distilled water was helpful in preventing accumulation of smear layer in dentinal tubule orifices than using $\mathrm{NaOCl}$ or EDTA alone. Counting of CFU showed that using a combination of 3\% Sodium Hypochlorite with 17\% EDTA was more effective in reducing bacterial contamination in dentinal tubules than using any of these irrigants individually.

Bystrom and Sundqvist [25] evaluated the clinical effectiveness of $\mathrm{NaOCl}$ irrigation and found that the combined use of $5 \% \mathrm{NaOCl}$ with EDTA was more efficient than using $\mathrm{NaOCl}$ solutions alone. Baumgartner and Mader [26] used scanning electron microscopy to evaluate the effects that $\mathrm{NaOCl}$ and EDTA used individually or in combination had on the removal of the smear layer and found that $\mathrm{NaOCl}$ and EDTA used in combination was more effective in removing smear layer that when these chemicals were used individually. However, their study focused on smear layer removal and not the eradication of microbes entrenched in dentinal tubules.

Berutti et al [27] studied histological sections obtained from dentin samples that had been artificially infected and found that a combination of $5 \% \mathrm{NaOCl}$ and $10 \%$ EDTA left residual dentinal infection to a depth of $300 \mu \mathrm{m}$. The results obtained in our study contrast with those obtained by Berutti [27]. In this study residual microorganisms were not detected when $17 \%$ EDTA and $3 \% \mathrm{NaOCl}$ were used in combination and alternating each cycle with distilled water. This difference may be explained by the higher irrigation volume and the constant refreshing of the irrigating solutions. Azim et al. [28] studied the effects of 4 irrigation protocols in eliminating bacteria from root canals especially in dentinal tubules, confocal analysis showed that to achieve better disinfection in the deeper dentin layers a device such as PIPS was needed [28]. Other observations from this study were that Sodium Hypochlorite at a $3 \%$ concentration showed a reduction in the formation of CFU but not to the degree of alternating $\mathrm{NaOCl}$ with EDTA. Also, using a 17\% solution of EDTA as a sole irrigant resulted in a negligible reduction in the formation of CFU. The positive control group consisted of irrigation solely with distilled water and had no effect whatsoever in the formation of CFU.

Interestingly alternating the order in which $\mathrm{NaOCl}$ and EDTA did not influence the effectiveness of the irrigating solutions in the disinfection of dentinal tubules. This could be explained that by replacing $1 \mathrm{ml}$ of the experimental irrigating solutions every 20 seconds until exposure to $3 \mathrm{ml}$ of solution per minute was reached allowed the dentin samples to be in continuous contact with fresh irrigation solution. In addition, each cycle was repeated until each protocol received $24 \mathrm{ml}$ of total exposure to the irrigating solutions thereby a higher irrigation volume was achieved while maintaining the freshness of the solutions utilized.

In this study dentin block samples were obtained from both the apical (a) and coronal (b) regions of the root to see if the difference in density and size of the dentinal tubules in the respective regions would have an effect in the capacity of the irrigating solutions to eradicate microorganisms harbored within the dentinal tubule lumen, even though apical dentin has smaller and more irregular dentinal tubules there was no difference in CFU reduction between apical dentin samples (a) and coronal dentin samples (b) in any of the groups tested [29].

The results of this study show that constant refreshing of $\mathrm{NaOCl}$ and EDTA irrigants, with water in between can be an effective way of achieving dentin disinfection at all levels of radicular dentin. Further research should study if the same results can be achieved with conventional irrigation through the root canal system particularly after shaping and cleaning procedures. In addition, it has been shown that prolonged exposure to EDTA can cause excessive removal of peritubular and intratubular dentin and it would be of interest to see if constant refreshing of EDTA solutions would have any deleterious effects on the structural integrity of these tissues [30]. It has been shown that agitating irrigating solutions can improve the effectiveness of irrigating solution in eradicating bacteria from the dentinal tubules a study designed to see if constant replenishing of the irrigating solutions in combination with agitating aids would increase the effectiveness of these devices would be of interest since this study showed that repeated replenishing of irrigating solutions will increase their effectiveness [24]. Also, when using $\mathrm{NaOCl}$, distilled water and EDTA the order in which these solutions did not affect the results however altering the irrigation sequence in chemo-mechanically prepared canals may show different results.

\section{Conclusion}

A combination of $3 \% \mathrm{NaOCl}$ and $17 \%$ EDTA solutions were more effective in reducing colony forming units than immersion in individual solutions of either 3\% sodium Hypochlorite or 17\% EDTA. The order in which these solutions were used did not have any effect on the results, rather it was more important to use these solutions in a dual irrigation protocol. No difference was observed between the samples of apical or coronal dentin despite the differences of diameter and number of dentinal tubules at both sites.

\section{Compliance with Ethical Standards}

\section{Conflict of interest}

Author 1 declares that he has no conflict of interest. Author 2 declares that he has no conflict of interest. Author 3 declares that he has no conflict of interest. Author 4 declares that he has no conflict of interest. Author 5 declares that he has no conflict of interest. Author 6 declares that he has no conflict of interest.

\section{Funding}

The work was supported by a seed grant (0012625) given to Dr. David E. Jaramillo from the Department of Endodontics, University of Texas Health Science Center at Houston, USA.

\section{Ethic approval}

This article does not contain any studies with human participants or animals performed by any of the authors. All procedures performed in studies involving human participants were in accordance with the ethical standards of the institutional and/or national research committee and with the 1964 Helsinki declaration and its later amendments or comparable ethical standards. 
The institutional Review Board (HSC-DB-18-0008) of the University of Texas Health Science Center at Houston has approved this research.

\section{References}

1. Kakehashi S, Stanley HR and Fitzgerald RJ. The effects of surgical exposures of dental pulps in germ-free and conventional laboratory rats (1965) Oral Surg Oral Med Oral Pathol 20: 340349. https://doi.org/10.1016/0030-4220(65)90166-0

2. Sundqvist G. Bacteriological studies of necrotic dental pulps (1976) Umeå University Odontol Dissertation, No 7. University of Umeå, Sweden,

3. Happasalo M, Endal U, Zandi H and Coil JM. Eradication of endodontic infection by instrumentation and irrigation solutions (2005) Endod Top10: 1-34. https://doi.org/10.1111/j.1601-1546.2005.00135.x

4. Zehnder M, Kosicki D, Luder H, Sener B and Waltimo T. Tissue dissolving capacity and antibacterial effect of buffered and unbuffered hypochlorite solutions (2002) Oral Surg 6: 756-762. https://doi.org/10.1067/moe.2002.128961

5. Sjogren U, Figdor D, Personn and Sundqvist G. Influence of infection at the time of root canal filling on the outcome of endodontic treatment of teeth with apical periodontitis (1997) Int Endod J 30: 297-306 https://doi.org/10.1111/j.1365-2591.1997.tb00714.x

6. Vieira AR, Siqueira Jr JE, Ricucci D and Lopes WSP. Dentinal tubule infection as the cause of recurrent disease and late endodontic treatment failure: a case report (2012) J Endod 38: 250-254. https://doi.org/10.1016/j.joen.2011.10.019

7. Gomes BP, Ferraz CC, Vianna ME, Berber VB, Teixeira FB, et al. In vitro antimicrobial activity of several concentrations of sodium hypochlorite and chlorhexidine gluconate in the elimination of Enterococcus faecalis (2001) Int Endod J: 34: 424-428. https://doi.org/10.1046/j.1365-2591.2001.00410.x

8. Arias-Moliz T and Morago A. Effects of dentin debris on the antimicrobial properties of Sodium Hypochlorite and Etridonic Acid (2016) J Endod 42: 771-775.

https://doi.org/10.1016/j.joen.2016.01.021

9. Peters OA, Schönenberger K and Laib A. Effects of four NiTi preparation techniques on root canal geometry assessed by micro computed tomography (2001) Int Endod J 34: 221-230. https://doi.org/10.1046/j.1365-2591.2001.00373.x

10. Torabinejad M, Handysides R, Khademi A and Bakland LK. Clinical implications of the smear layer in endodontics: A review (2002) Oral Surg Oral Med Oral Pathol Oral Radiol Endod 94: 658-666. https://doi.org/10.1067/moe.2002.128962

11. Al-Nazhan S, Al-Sulaiman A, Al Rasheed F, Alnajjar F, AlAbdulwahab B, et al. Microorganism penetration in - dentinal tubules of instrumented and retreated root canal walls. In vitro SEM study (2014) Restor Dent Endod 39: 258-264. https://doi.org/10.5395/rde.2014.39.4.258

12. Violich D and Chandler MP. The smear layer in endodontics- A review (2010) Int Endod J 43: 2-15. https://doi.org/10.1111/j.1365-2591.2009.01627.x

13. Haapasalo HK, Siren EK, Waltimo TM, Ørstavik D and Haapasalo MP. Inactivation of root canal medicaments by dentine: an in vitro study (2000) Int Endod J 33: 126-131. https://doi.org/10.1046/j.1365-2591.2000.00291.x

14. McComb D, Smith DC and Beagrie GS. The results of in vivo chemomechanical instrumentation: a scanning electron microscopic studies (1976) J Br Endod Soc 9: 11-18. https://doi.org/10.1111/j.1365-2591.1976.tb01231.x
15. Haapasalo $M$ and Ørstavik D. In vitro infection and disinfection of dentinal tubules (1987) J Dent Res 66: 1375-1379. https://doi.org/10.1177/00220345870660081801

16. Wang HH, Daniel SL, Sleiman P, Dorn SO and Jaramillo DE. Smear layer and debris removal from dentinal tubules using different irrigation protocols: scanning electron microscopic evaluation, an in vitro study (2017) Evid Bas Endodon 2: 5. https://doi.org/10.1186/s41121-017-0011-4

17. Goldman M, Goldman LB, Cavaleri R, Bogis J and Lin PS. The efficacy of several endodontic irrigating solutions: a scanning electron microscopic study: part 2 (1982) J Endod 8: 487-492. https://doi.org/10.1016/s0099-2399(82)80073-3

18. Dahlen G, Linden A, Moller AJR and Ohman A. A retrospective study of microbiological samples from oromucosal lesions (1982) Oral Sur Oral Med Oral Pathol 53: 250-255. https://doi.org/10.1016/0030-4220(82)90299-7

19. Gutierrez JH and Garcia J. Microscopic and macroscopic investigations on results of mechanical preparation of root canals (1971) Oral Surg 31: 108-116. https://doi.org/10.1016/0030-4220(68)90204-1

20. Oguntebi BR. Dentine tubule infection and endodontic therapy implications (1994) Int Endod J 27: 218-222. https://doi.org/10.1111/j.1365-2591.1994.tb00257.x

21. Shovelton DS. The presence and distribution of microorganisms within non- vital teeth (1964) Br Dent J 117: 101-107.

22. Sedgley CM, Lennan SL and Appelbe OK. Survival of Enterococcus faecalis in root canals ex vivo (2008) Int Endod J 38: 735-742. https://doi.org/10.1111/j.1365-2591.2005.01009.x

23. Sedgley CM. Root canal irrigation-A historical perspective (2004) J Hist Dent 52: 61-65.

24. Prado M Santos, Junior HM, Rezende CM, Pinto AC, Faria RB, et al. Interactions between irrigants commonly used in endodontic practice: a chemical analysis (2013) J Endod 39: 505-510. https://doi.org/10.1016/j.joen.2012.11.050

25. Bystrom A and Sundqvist G. The antibacterial action of sodium hypochlorite and EDTA in 60 cases of endodontic therapy (1985) Int Endod J 18: 35-40. https://doi.org/10.1111/j.1365-2591.1985.tb00416.x

26. Baumgartner JC and Mader CLA. Scanning electron microscopic evaluation of four root canal irrigation regimens (1987) J Endod 13: 147-157. https://doi.org/10.1016/s0099-2399(87)80132-2

27. Berutti E, Marini $R$ and Angeretti A. Penetration ability of different irrigants into dentinal tubules (1997) J Endod 23: 725727. https://doi.org/10.1016/s0099-2399(97)80342-1

28. Azim AA, Aksel H, Zhuang T, Mashtare T, Babu JP, et al. Efficacy of 4 irrigation protocols in killing bacteria colonized in dentinal tubules examined by a novel confocal laser scanning microscope analysis (2016) J Endod 42: 928-934. https://doi.org/10.1016/j.joen.2016.03.009

29. Giudice LG, Cutroneo G, Centofanti A, Artemisia A, Bramanti E, et al. Dentin morphology of root canal surface: A quantitative evaluation based on a scanning electronic microscopy study (2015) Biomed Res Int 164065. https://doi.org/10.1155/2015/164065

30. Calt S and Serper A. Smear layer removal by EGTA (2000) J Endod 26: 459-461. https://doi.org/10.1097/00004770-200008000-00007 